Christian von Bar

\title{
Tort Law in the Revised Moldovan Civil Code and the Draft Common Frame of Reference (DCFR)*
}

\begin{abstract}
:
The article analyzes the provisions of the new Moldovan CC about tort law. It describes the similarities and differences between the Moldovan CC and the sixth book of the DCFR. (The article reproduces the revised text of a lecture the author gave on October 4, 2018 in Chişinău. The form of the speech has been maintained.)
\end{abstract}

\section{Introduction}

It is with the greatest delight that I accepted the invitation to this conference. I have never been in Moldova before. In my youth it belonged to the regions of Europe which were practically out of reach for us living in the western parts of the continent. An iron curtain had divided us in the aftermath of the horrible war which the German Nazi-Regime had started, a monstrous crime and a shame with which my generation had to live. The happier I am that today we have a chance to discuss matters of common interest together, in my case matters of "tort" law, as the English terminology has it. (I will use this expression as a short-hand formula throughout my paper, although, strictly speaking, "torts" require a common law surrounding; our civilian systems have no "torts".) I will try to compare the text of the new Moldovan Civil Code with the tort law approach chosen by the DCFR. In doing so I will rely on an English translation of the (draft) Code made available to me in 2018. ${ }^{1}$ I cannot read the Code in its own language.

I don't wish to start without saying that my main problem is time. I cannot exhaust my subject, but I can certainly exhaust my audience. I have to concentrate on a few issues of central significance, and I will not repeat here the history of the DCFR

* von Bar, Christian, Prof. Dr. jur. Dr. h.c. mult., FBA, Universität Osnabrück, geschäftsführender Direktor des European Legal Studies Institute (ELSI) in Osnabrück.

1 By Dr. Octavian Cazac, Chişinău, who also translated Arts. 19 and 20 mold. CC. The chapter on tort law was translated by Marina Bzovii, Chişinău. An official English translation of the mold. CC that came into force on March 1, 2019, is not yet available. However, the final text deviates from the English translation of the draft provided to me only in the article count. This contribution cites the articles (based on their translation into Russian) in their current census. The chapter heading has also changed. While in the draft of 2018 the heading of the Chapter on torts was "Non-contractual Liability arising out of Damage caused to another", it was before its final adoption by Parliament renamed into "Delictual Liability" (Răspunderea delictuală). This change was probably made for reasons of consistency of references, as, for instance, in the rules on limitation periods there were (and are) references to claims arising out of "delictual liability". 
and of the academic groups who drafted it. I also do not wish to start without having said how pleased I am to see that the drafting committee, the Moldovan government and the Moldovan parliament thought it worthwhile to consider the DCFR as a source of inspiration. Its main influence is certainly on the renewed contract law, but there are also plenty provisions in the Code's chapter on tort law which remind me of our pan-European deliberations.

\section{Examples of common provisions}

Let me give a few examples. Colleagues from Moldova know them, of course, much better than I do, but mentioning these rules might be interesting for colleagues from other jurisdictions. In preparing my contribution I first saw Art. 2003 mold. CC which clearly resembles DCFR VI.-5:203 on "protection of public interest". It is an important rule for the protection of the freedom of the press. (The wording of these and all other provisions and rules can be found in a synopsis which I attach to the end of this paper in the order in which I refer to them). I was impressed by the strength of Art. 2004 mold. CC, a rule that the DCFR should have had but regrettably did not work out. The article says: "Performance of an activity imposed or allowed by law or by superior's order does not exclude the liability of the one who may have realized the unlawful nature of his deed, committed in such circumstances". The nearest equivalent of the DCFR is in its definition of negligence, i.e. in DCFR VI.-3:102(b). The idea, however, is the same. One cannot hide behind a statutory instrument if one realises or should have realised that under the circumstances of the case a higher standard of care is required than the statutory instrument prescribes. A further rule that we have in common is in Art. 2012 mold. CC and in DCFR VI.-5:302: the "event beyond control". It is far from self-evident that we also share the rule about abandonment (Art. 2017 mold. CC; DCFR VI.-3:208). We are, furthermore, in complete agreement in respect of the rules on loss upon reliance on incorrect advice or information (mold. CC Art. 2018; DCFR VI.-2:207). And Moldova is to my knowledge the first country in the world which codified the "tort" of unlawful impairment of business (Art. 2019 mold. CC; DCFR VI.-2:208), originally developed by German case law. A very substantial (and unexpected) step forward is Art. 2020 mold. CC (the equivalent to DCFR VI.-2:209) on burdens incurred by the state upon environmental impairment. Let us pray that this rule will never be needed, but it is of utmost importance to have it if something really bad and severe happens. It has all the ingredients of a rule that might one day write legal history.

I cannot stop this first survey without directing your attention to three further provisions. The first is in Art. 2022 mold. CC (to be read in conjunction with Art. 2023 mold. CC) which in an elegant way bring(s) together DCFR VI.-4:101 to 4:103. These are the rules on causation. They belong to the three pillars upon which every system of tort law rests; the other two being the concept of damage and the concept of attribution. The key message is that causation is not a mere matter of facts, causation is a normative concept. That is why the rule (I quote from the CC) says that "a person causes the damage if it is to be regarded as a consequence of that person's conduct or the source of danger for which that person is responsible" (italics added). Indeed, cau- 
sation is a matter of law. It "translates" an observable sequence in time into an unobservable reason. It is not enough to demonstrate that something happened "after" another event has occurred; it is necessary to give an explanation "why" it happened. Consequently we do not apply the same tests in fault-based and in strict liability. The causal test is not even the same in cases of negligence and of intention, and also not the same in such areas as damage to property, damage to the bodily integrity and damage to the personal dignity of a person.

There are so many more convictions that we share that I find it impossible to refer to all of them. Allow me to direct your attention to the provisions on damages (Art. 2025 mold. CC; DCFR VI.-6:101). The mold. CC also accepted DCFR VI.-6:101(4) on skimming off of profits (Art. 19(6) mold. CC). Both the Moldovan Civil Code and the DCFR have an innovative rule on liability for loss in preventing damage (Art. 2027 mold. CC; DCFR VI.-6:302) which, I think, will play a considerable role in practice. But there is also (another) truly sensational rule, the one on biological damage (Art. 2028 mold. CC) which seems to have its origin in DCFR VI.-6:204. "Bodily injury" it says, "or injury to health is to be compensated independent of compensation for economic or non-economic loss, separate compensation for the injury itself (biological damage)". I am not sure whether the English translation is completely correct here, but that is unimportant. It is the substance that counts. The concept of the danno biologico is of Italian origin, of course. It is a splendid example of a genuine legal "invention".

The new Moldovan Civil Code, in its section on tort law, is a very impressive text, modern, intellectually demanding and evidence of a society determined to meet the needs of our times. It demonstrates what comparative law and European co-operation can achieve, and it shows how advanced the science of law in this country is. We, in Germany, are, in tort law, still living under a codification which resembles a museum piece when you compare it with what Moldova has since the $1^{\text {st }}$ of March 2019.

\section{The basic rules and their consequences for the internal structure of the texts}

Having said this I cannot hold back a few further observations. I regard it as a pity that the Moldovan legislator changed the heading of the $34^{\text {th }}$ chapter of the $\mathrm{CC}$ in the last minute, and I note that the internal structures of that chapter and of the $6^{\text {th }}$ book of the DCFR deviate substantially. The DCFR refers to "Non-contractual Liability arising out of Damage caused to another". The Moldovan CC, however, now refers to "delictual liability" (only the draft also had "non-contractual liability arising out of damage caused to another"). Furthermore, the Moldovan CC subdivides this chapter in only two sections ("General Provisions" and "Liability for Damage Inflicted by Defective Products"), the DCFR needs seven: (1) Fundamental Provisions, (2) Legally relevant damage, (3) Accountability, (4) Causation, (5) Defences, (6) Remedies, and (7) some "Ancillary rules". You might say that this point is much too banal to be made. I would argue it is not. Give me a chance, please, to explain this as briefly as I can. 
The change back to "delictual liability" might indeed facilitate cross-references within the Code, ${ }^{2}$ but I would also like to defend our "non-contractual liability arising out of damage caused to another". I believe it is more correct. That is so because modern tort law is no longer based on misconduct alone. Illegality (or wrongfulness) and fault are not anymore the only and, in some jurisdictions, not even the most important reasons to be held liable for a damage. To speak of "delicts" is, therefore, not accurate. "Delict" has its origin in Latin delinquere (to "come off the right way" and thereby "trespass" a border and, later, a rule of law). Keeper's or guardian's liability are in that sense not delictual in nature. A keeper is not liable for any "misconduct", not because he or she is liable without fault, but because they are liable without any legally relevant "conduct" at all. He or she is not liable because they deviated from anything the law requires a person to do or to omit. A keeper may have behaved perfectly correctly, but he or she is nevertheless held liable. We are in the area of so-called strict liability, and the borderline between this form of liability and negligence-based liability (which also more often than not amounts to a liability without "fault") runs exactly here: in the latter one is liable because one fell short of a given standard of behaviour, in the former one is liable although the law does not criticise what one actually did. That, in turn, means that there is also no causal link between a given conduct and a resulting damage. The causal link is solely between the source of danger and the damage. For instance: whilst I am speaking here one of our sons might be driving our family car of which I am the keeper. Should he get involved in a traffic accident I will be liable vis-à-vis third parties for the consequences. But I haven't done or omitted anything that could reasonably be regarded as having contributed to the accident. It is the (use of the) car that caused the damage.

It follows, at least in my view, that a modern tort law regime should start from the victim's, not from the tortfeasor's perspective. The damage forms the starting point, not a qualification of what the defendant did or omitted. Only then are we able to bind intention-based, negligence-based and strict liability together in one overarching approach. I am not saying this to criticise the Moldovan approach, I am simply trying to explain our own. And I don't want to be misunderstood. We both share the view that various details of intention- or negligence-based liability and "strict" liability (again a very unclear expression, because every liability, once arisen, is strict) need to be treated separately. Art. 1998(2) mold. CC ("damage caused through legal acts or without fault shall be compensated for only in cases expressly provided by the law") does not come as a surprise either. Its political message is clear; we have a similar rule in DCFR VI-1:101(2). The theoretical problem, however, remains, because it is rather difficult to formulate a starting point which explains that both forms of liability follow at least the same basic structure. As said before, everything in tort law can be reduced to its three core elements: damage, attribution and causation.

Art. 1998(1) mold. CC follows the classical approach of practically all continental systems. It is not far away from a so-called "general clause", although it seems definitely closer to its equivalents in e.g. Greece, Italy and even Germany than to the famous French model. That is due to the fact that the Moldovan CC has retained the notion of "illegality" or "wrongfulness". From a point of legal policy that is very well

2 See fn. 1. 
understandable; such a restricted approach contributes to legal stability. The DCFR's solution is more radical: it gave up the concept of "illegality" ("wrongfulness") altogether, remaining thus a bit closer to the starting point: the "non-contractual liability arising out of damage caused (not "by" but rather) to another". Its basic rule (DCFR VI-1:101(1)) reads: "A person who suffers legally relevant damage has a right to reparation from a person who caused the damage intentionally or negligently or is otherwise accountable for the causation of the damage." One must read it, however, in conjunction with DCFR VI.-1:103(a) (under which the basic rule applies "only in accordance with the following provisions of this Book"). The idea was to describe those situations step by step and in more detail in which the negative result of a given behaviour or the negative result of the realisation of a specific risk does indeed constitute a "legally relevant damage" as we called it. Only in exceptional cases does one have to fall back on DCFR VI.-2:101(b) and (c). That approach has also some disadvantages although it makes it visible how closely damage, accountability and causation interact.

Be that as it may. In any case we can now explain the differences in the internal structure of both texts. The DCFR, for instance, has only "defences" because, when you abandon the concept of wrongfulness, you necessarily also abandon the concept of "justification". In terms of legal policy that does not, however, matter very much. All "defences" have in common that the burden of proof is on the defendant. As far as substance is concerned I have again found many striking similarities between the mold. CC and the DCFR. One example among many can be found in the rules on informed consent (Art. 1998(4) mold. CC; DCFR VI.-5:101(1)). The mold. CC does not, however, contain a specific rule on risk acceptance (DCFR VI.-5:101(2)). And it did not, once again not a real surprise, accept our "de minimis rule" (DCFR VI.-6:102). We had an argument about it also among ourselves. The rule on consent (Art. 1998(4) mold. CC) is qualified in that it excludes unethical behaviour of the tortfeasor. The drafters of the DCFR left that to criminal law, because (forgive me for not being $100 \%$ serious now) we thought that the gentleman who sees his "domina" should not, after having received her "service", be able to sue her for "pain and suffering"!

One could, at first sight, be much more worried by the fact that the Code nowhere defines or explains what in its view constitutes "illegality". It is most probably the infringement of an absolute right and the infringement of a statutory provision. Whether that is a sufficient basis, is, however not easy to say. Most of the particularly difficult matters of liability for pure economic losses are indeed covered by the rules I mentioned in the beginning, and also by Art. 2021 mold. CC (DCFR VI.-2:210) on fraudulent misrepresentation. But I fear that after a while cases will come up which are difficult to solve under this approach. One example: I have just tried to get tickets for the Hamburg concert house Elbphilharmonie. The official winter programme gave a telephone no. I called there - and ended up at a dentist's! The number was misprinted; this poor doctor's telephone rang every five minutes. Illegality?

Speaking about rights. The Code's provisions on tort law have hardly anything on incorporeal personality rights (dignity, privacy, reputation and the like). That astoun- 
ded me. But Moldova has, since 2010, a modern "Law on Freedom of Expression". 3 Its title is narrower than its content. It also deals with the protection of the individual person against abuses of the freedom of the press and other media. Art.7(1) of the said law reads: "Everyone has the right to honor, dignity and professional reputation damaged by spreading false reports about the facts, value judgments without sufficient factual basis or injury." I am, however, less sure that incorporeal personality rights are only endangered by the media. Infringements of privacy are a day-to-day occurrence in our private lives as well. DCFR VI.-2:203(1) therefore opted for a general rule and mentions expressly "the rights to liberty and privacy". Honor and reputation, on the other hand, are more complicated issues (DCFR VI.-2:203(2)). Here one might indeed need specific legislation. The most worrying danger for the right to personal dignity originates, however, in the internet. The law has a huge task here. Allow me to add that I can also see a point in the argument that our modern societies should develop a fundamentally reshaped law of the natural person. The Moldovan approach seems to follow this line already. The key question, however, still awaits an answer, in Moldova no less than in all other parts of Europe: Do we have to draw afresh the borderline between the law of the person and tort law?

\section{Tort law and the general law of obligations}

Mentioning this point leads me to another observation. Time might be ripe to ask ourselves whether the classical "general parts" (of the Code and of its law of obligations) are, in their current form, still apt for future generations. I know that this is nothing for a German to ask; Germany is, in that respect, the world's champion. But can we still convincingly assume that, to give but two examples, the law on damages is the same in contract and in tort, and can we also still assume that definitions of intention and negligence should be identical regardless of the context in which they are needed? The DCFR is no Code, it was drafted as a source of inspiration to law-makers, courts and academics. Strictly speaking it did not have to answer that question. But it indicated a tendency. The DCFR placed its definitions of intention (VI.-3:101) and negligence (VI.-3:102) in its Book on non-contractual liability for damage caused to another, neither in its first Book ("General provisions") nor in its second ("Contracts and other juridical acts") (and when you check the list of definitions you find no entry for "intention" and an entry for "negligence" which is (deliberately) not a one-to-one repetition of the rule in tort law). The mold. CC, in contrast, opted for the more traditional solution. Arts. 19 and $20 \mathrm{CC}$ placed there rules on damages ("reparation of loss"), intention and negligence in the Code's general part. When it comes to details, there is a lot to observe in both the rules of the Code and the DCFR. One point might be highlighted: the clear answer that Art. 19(4) mold. CC gives to the tricky question of "loss of chance". "Loss of chance shall be repaired only if it consists in the actual and certain disappearance of a favourable eventuality. The amount of such loss corresponds to the lost chance and cannot be equal to the advantage which would have

3 English translation at https://www.lawyer-moldova.com/2012/09/law-on-freedom-of-expre ssion.html. 
been derived if the chance had materialized". Here again one finds a victim-friendly rule which, in principle, I applaud. The DCFR, however, is less straightforward in this point (VI.-2:101(3)). I can clearly see the advantages of the Moldovan rule in cases of doctor's liability. But what if someone suffers an accident shortly before the date of his exam? Would you say that he or she is also entitled to damages because he lost the chance to pass his exam in time? And how would one have to measure the student's losses in such a case?

\section{Liability for others and strict liability}

Before concluding I would like to say a few words about liability for others and strict liability. There is a certain imbalance in the Code here, but that is really a very minor point to start with. The simple explanation for the removal of liability for defective products into a section of its own seems to be that the legislator wanted to more or less copy the Directive word by word in order to avoid any drafting difficulties. Moldova, by the way, did not opt for the $500 €$ threshold in cases of damage to property. The DCFR did not do so either.

I have already mentioned Art. 1998(2) mold. CC. It is, however, not that easy to understand the differentiation between "strict" liability on the one hand and "liability for others" (Art. 1998(3) mold. CC) on the other. I myself would have thought that socalled "liability for others" is either liability for one's own negligence (even if rebuttably presumed) or in itself a form of strict liability. Maybe I missed a point here because I have found it difficult to understand which cases Art. 1998(3) mold. CC addresses. In the following provisions the Code captures all (or nearly all) situations which have so far been discussed in case law and academic writing. That includes liability for damage caused by a person under a legal protection measure (Art. 2010 mold. CC; see also DCFR VI.-3:104(2)). But what if elderly people, not living under a legal protection measure, leave their old person's home and stumble, or if children in a kindergarden run onto the street and cause an accident which could in both alternatives have been avoided had the staff acted with due care? Would that come under Art. 1998(3) loc. cit.? Probably not, at least not in the kindergarden example, because of Art. 2008(2) mold. CC.

Liability for employees seems to be strict (Art. 2005(1) and (2) mold. CC); that is in line with DCFR VI.-3:201(1). There are minor differences in the wording here ("during exercise of the functions"; "in the course of the employment or engagement"), but I doubt that they affect substance. That the "agent" acts with intention does not, in itself, exonerate the principal of liability. Abuse of children by priests (the press in my country recently reported of more than 1000 abused and even raped kids in Pennsylvania) must lead to liability of the diocese. Liability for children, on the other hand, is not strict (Arts. 2008(1), 2009(2) mold. CC; DCFR VI.-3:104(3)). Strict parental liability might even cause a problem of constitutional law because one might argue that it runs contrary to the protection of the family. It should, however, be understood that failure to supervise one's kids renders both parents liable, independent of who of them is out at work or at home and actually in care of the kids. 
In strict liability in its narrow Moldovan understanding there is of course the ageold liability for animals (Art. 2014(1) mold. CC; DCFR VI.-3:203). The main difference between our texts is that under Moldovan law the liability is, as a rule, on the owner, not, as under the DCFR, on the keeper. Another classic issue is liability for defective buildings. Here we do find some significant differences. Under Art. 2015(1) mold. CC liability is again on the owner, not, as under DCFR VI.-3:202(1) and (2) on the person who "independently exercises control over an immovable". DCFR VI.-3:202(3) does, however, rebuttably presume that that is the owner. In contrast to the DCFR the Moldovan CC still has the actio de effusis vel ejectis (Art. 2016 mold. CC). That is an arguable point. China, for instance, has just reintroduced this rule. The example one had in mind was a heavy ashtray which fell out of a skyscraper and badly injured a pedestrian. Much more important, however, is that DCFR VI.-3:202 deals with "accountability for damage caused by the unsafe state of an immovable", not merely with "liability for damage caused by collapse of a building" (italics added in both instances). Holes in the ground are hardly less dangerous than pieces falling down from above. We also thought that the famous culpa in contrahendo-cases (customers in a supermarket fall down and injure themselves because a banana peel was not removed in time) should be better treated here than in a somewhat mysterious area of contract law.

When it comes to strict liability most of us will spontaneously think of car accidents law. The latter remained, it seems to me, somewhat neglected. It comes under Art. 2013 mold. CC, the Soviet-style general clause on "liability for damage caused by [a] source of increased danger". Such a general clause is quite obviously not without risk for legal certainty, even though Art. 2013(1) loc. cit. gives a (non-exhaustive) list of examples: exploitation of vehicles, installations, mechanisms, use of electric energy, explosives, construction works etc). Personally I doubt that the theoretical concept of liability for "increased danger" is correct. We have no proper means to measure the degrees of danger, and I find it unconvincing to try to explain all instances of strict liability with the use of one and the same argument. The DCFR in any event does not follow this theory. Instead, the DCFR deals with accountability for damage caused by motor vehicles (DCFR VI.-3:205) and accountability for damage caused by dangerous substances or emissions (DCFR VI.-3:206), and leaves all other instances to national law (DCFR VI.-3:207). There is no other area in tort law where Europe is more divided than in the area of strict liability. One reason to differentiate between its various types is, by the way, that the notion of damage varies substantially from one form of it to the other.

\section{Concluding remarks}

Tort law covers a wide range of subject matters; it is not smaller than contract law. It is not possible to mention every aspect. Concurrence of actions, for instance, is a matter which would require lengthy treatment in its own right. I cannot do more than to highlight that, once again, the Moldovan CC and the DCFR seem to be in complete harmony in this field (Art. 1999(2) and (3) mold. CC; DCFR VI.-1:103(c) and (d)). In conclusion it is hopefully fair to say that the Moldovan CC in its modernised version 
combines traditional with completely new approaches. It is an impressive piece of legislation. I am happy that I had an opportunity to read and analyze it. If there is something that future generations might wish to think about afresh that might be the law of strict liability. But that is not for me to say. For me it is enough to say that I admire the work done in this country.

\section{Synopsis}

\begin{tabular}{|c|c|}
\hline $\begin{array}{l}\text { Moldovan CC, version in force since } 1^{\text {st }} \\
\text { March, } 2019^{4}\end{array}$ & DCFR \\
\hline $\begin{array}{l}\text { Art. 2003: "Public interest protection } \\
\text { Damage compensation is excluded if it } \\
\text { is due to the protection of the fundamen- } \\
\text { tal values necessary in a democratic so- } \\
\text { ciety, especially when caused by the dis- } \\
\text { closure of information by the press". }\end{array}$ & $\begin{array}{l}\text { VI.-5:203: "Protection of public inte- } \\
\text { rest } \\
\text { A person has a defence if legally rele- } \\
\text { vant damage is caused in necessary pro- } \\
\text { tection of values fundamental to a demo- } \\
\text { cratic society, in particular where dama- } \\
\text { ge is caused by dissemination of infor- } \\
\text { mation in the media". }\end{array}$ \\
\hline $\begin{array}{l}\text { Art. 2004: "Performance of an Activity } \\
\text { Imposed or Allowed by Law } \\
\text { Performance of an activity imposed or } \\
\text { allowed by law or by superior's order } \\
\text { does not exclude the liability of the one } \\
\text { who may have realized the unlawful na- } \\
\text { ture of his deed, committed in such cir- } \\
\text { cumstances". }\end{array}$ & $\begin{array}{l}\text { VI.-3:102(b): "Negligence } \\
\text { A person causes legally relevant damage } \\
\text { negligently when that person causes the } \\
\text { damage by conduct with either (a) [...] } \\
\text { or (b) does not otherwise amount to such } \\
\text { care as could be expected from a reason- } \\
\text { ably careful person in the circumstances } \\
\text { of the case". }\end{array}$ \\
\hline $\begin{array}{l}\text { Art. 2012: "Event beyond control } \\
\text { A person shall not be liable if the dama- } \\
\text { ge is caused by an abnormal event } \\
\text { which cannot be averted by any reason- } \\
\text { able measure and which is not to be re- } \\
\text { garded as that person's risk". }\end{array}$ & $\begin{array}{l}\text { VI.-5:302: "Event beyond control } \\
\text { A person has a defence if legally rele- } \\
\text { vant damage is caused by an abnormal } \\
\text { event which cannot be averted by any } \\
\text { reasonable measure and which is not to } \\
\text { be regarded as that person's risk". }\end{array}$ \\
\hline $\begin{array}{l}\text { Art. 2017: "Abandonment } \\
\text { A person remains accountable for the } \\
\text { damage caused by a building, source of } \\
\text { increased danger, which that person } \\
\text { abandons until other takes possession of } \\
\text { the building, or exercises independent } \\
\text { control or operates it. This applies corre- } \\
\text { spondingly, so far as reasonable, in re- } \\
\text { spect of a keeper of an animal". }\end{array}$ & $\begin{array}{l}\text { VI.-3:208: "Abandonment } \\
\text { For the purposes of this section, a person } \\
\text { remains accountable for an immovable, } \\
\text { vehicle, substance or installation which } \\
\text { that person abandons until another exer- } \\
\text { cises independent control over it or be- } \\
\text { comes its keeper or operator. This ap- } \\
\text { plies correspondingly, so far as reason- } \\
\text { able, in respect of a keeper of an ani- } \\
\text { mal". }\end{array}$ \\
\hline
\end{tabular}

4 Headings in square brackets are mine; they are not part of the Code. 


\section{Art. 2018: "Damage Suffered Due to Trust in a Consultation or Incorrect Information}

(1) The damage suffered by a person as result of a decision taken by reasonably believing in an incorrect consultation or information shall be compensated if:

a) the consultation or the information is provided by a professional in the course of its activity; and

b) the person who offered the consultation or information knew or could reasonably be expected to know, that the recipient of the consultation or of the information would rely on it, when making that decision.

(2) The liability provided by this article occurs only to the extent that the person who provided the consultation or the information limited or excluded the liability".

Art. 2019: "Loss upon Unlawful Impairment of Business

(1) The person who unlawfully impairs or precludes the business of a professional is obliged to compensate the damage caused thereby.

(2) The consumer is entitled to compensation of damage for the loss caused as a result of unfair competition within the meaning of Competition Law".

Art. 2020: "Burdens Incurred by the Public Authority upon Restoring the Environmental Damage

Burdens incurred by the designated competent public authorities in restoring impaired natural elements constituting the environment, such as air, water, soil, flora and fauna, as a result of a relevant damage, is to be compensated to the public authorities concerned".
VI.-2:207: "Loss upon reliance on incorrect advice or information

Loss caused to a person as a result of making a decision in reasonable reliance on incorrect advice or information is legally relevant damage if:

(a) the advice or information is provided by a person in pursuit of a profession or in the course of trade; and

(b) the provider knew or could reasonably be expected to have known that the recipient would rely on the advice or information in making a decision of the kind made".
VI.-2:208: "Loss upon unlawful impairment of business

(1) Loss caused to a person as a result of an unlawful impairment of that person's exercise of a profession or conduct of a trade is legally relevant damage.

(2) Loss caused to a consumer as a result of unfair competition is also legally relevant damage if Community or national law so provides".

VI.-2:209: "Burdens incurred by the state upon environmental impairment Burdens incurred by the State or designated competent authorities in restoring substantially impaired natural elements constituting the environment, such as air, water, soil, flora and fauna, are legally relevant damage to the State or the authorities concerned". 


\section{Art. 2022: "Causation}

(1) A person causes the damage if it is to be regarded as a consequence of that person's conduct or the source of danger for which that person is responsible.

(2) In cases of personal injury or other injury to health or death, the injured person's predisposition with respect to the type or extent of the injury sustained is to be disregarded.

(3) Where the damage may have been caused by any one or more of a number of occurrences for which different persons are accountable and it is established that the damage was caused by one of these occurrences but not which one, each person who is accountable for any of the occurrences is rebuttably presumed to have caused that damage, until proven otherwise".

\section{Art. 2023: "Liability for Jointly Cau-}

\section{sed Damage}

(1) Where the damage was caused jointly by several participants, they shall bear joint and several liabilities.

(2) Participant shall be considered not only by the author of the deed that caused the damage, but also by the one who instigated the former or supported him, as well as by the one that knowingly benefited from the damage caused to another person (participants).

(3) In case of recourse action, the share of each participant in the joint obligation shall be proportionate with the contribution to the deed, if it can be determined".

\section{VI.-4:101 “General rule}

(1) A person causes legally relevant damage to another if the damage is to be regarded as a consequence of that person's conduct or the source of danger for which that person is responsible.

(2) In cases of personal injury or death the injured person's predisposition with respect to the type or extent of the injury sustained is to be disregarded".

\section{VI.-4:102: “Collaboration}

A person who participates with, instigates or materially assists another in causing legally relevant damage is to be regarded as causing that damage".

\section{VI.-4:103: “Alternative causes}

Where legally relevant damage may have been caused by any one or more of a number of occurrences for which different persons are accountable and it is established that the damage was caused by one of these occurrences but not which one, each person who is accountable for any of the occurrences is rebuttably presumed to have caused the damage". 


\section{Art. 2025: "Order of Compensation for Damage}

(1) Damage compensation shall be made in kind, re-establishing the status quo ante (the previous situation) (the transmission of a good of the same kind and quality; repairing the damaged item etc.), and if this is not possible or if the injured person is not interested in compensation in kind, by payment of the equivalent damage in money (compensation), as established by the agreement of the parties, in absence, established by court decision.

(2) Where a tangible object is damaged, compensation equal to its value depreciation is to be awarded instead of the cost of its reparation if the cost of reparation unreasonably exceeds the depreciation of value. This rule applies to animals only if appropriate, having regard to the purpose for which the animal was kept.

(3) The damage is calculated as a lump sum and, in case of a continuous damage, in the form of a periodical payment. Where compensation is established in form of a periodical payment, the debtor may be required to lodge a security.

(4) The person suffering the damage is not required to prove whether or not the compensation was spent on the reinstatement of the damaged interest.

(5) In case of a future damage, the compensation, regardless of the form in which it was granted, may be increased, reduced or extinguished, if, after the determination of the damage, it has increased, diminished or was extinguished.

(6) The author of the unlawful deed is also liable for the interest rate as established by Art. 623/20, starting with the date when the liable person for the damage received a formal notice from the person suffering the damage. The default interest shall be calculated from the amount of the compensation or, in case of compensation in kind, out of the value of reparation".
VI.-6:101(1)-(3): “Aim and forms of reparation

(1) Reparation is to reinstate the person suffering the legally relevant damage in the position that person would have been in had the legally relevant damage not occurred.

(2) Reparation may be in money (compensation) or otherwise, as is most appropriate, having regard to the kind and extent of damage suffered and all the other circumstances of the case.

(3) Where a tangible object is damaged, compensation equal to its depreciation of value is to be awarded instead of the cost of its repair if the cost of repair unreasonably exceeds the depreciation of value. This rule applies to animals only if appropriate, having regard to the purpose for which the animal was kept. 


\begin{abstract}
Art. 19(6): [Skimming off of profits] „In lieu of reparation of patrimonial loss under paragraphs (2) and (5), the aggrieved person may claim from the person held responsible for the loss of the entire profit it obtained in connection with the causation of the loss. This rule shall apply only if the law or the contract provides such a form for determination of patrimonial loss or if the application of such a form of determination of patrimonial loss is reasonable in the circumstances of the case".
\end{abstract}

Art. 2027: "Liability for Loss in Preventing Damage

A person who has reasonably incurred expenses or suffered other loss in order to prevent that person from suffering an impending damage, or in order to limit the extent or severity of damage suffered, has a right to compensation from the person who would have been accountable for the causation of the damage".

Art. 2028: "Compensation of the Damages Caused by Bodily Injury or Injury to Health

(1) Bodily injury or injury to health is to be compensated independent of compensation for economic or non-economic loss, separate compensation for the injury itself (biological damage)".

Chapter XXXIV: "Liability arising out of delict"

Two sections: “(1) General Provisions, (2) Liability for Damage Inflicted by Defective Products“"
VI.-6:101(4):

(4) As an alternative to reinstatement under paragraph (1), but only where this is reasonable, reparation may take the form of recovery from the person accountable for the causation of the legally relevant damage of any advantage obtained by the latter in connection with causing the damage".

\section{VI.-6:302: "Liability for loss in} preventing damage

A person who has reasonably incurred expenditure or sustained other loss in order to prevent that person from suffering an impending damage, or in order to limit the extent or severity of damage suffered, has a right to compensation from the person who would have been accountable for the causation of the damage".

\section{VI.-6:204: "Compensation for injury} as such

Injury as such is to be compensated independent of compensation for economic or non-economic loss".

Book VI: "Non-contractual liability arising out of damage caused to another"

Seven chapters: "(1) Fundamental Provisions, (2) Legally relevant damage, (3) Accountability, (4) Causation, (5) Defences, (6) Remedies, (7) "Ancillary rules"", 


\section{Art. 1998: [Liability without illegality or fault]}

(2) "The damage caused through legal acts or without fault shall be compensated for only in cases expressly provided by law.

(3) A person other than the author of the damage shall be bound to compensate for it only in cases expressly provided by law".

Art. 1998: [Liability without illegality or fault ]

(1) "A person who commits an illegal and imputable act towards another person is bound to compensate him for damage caused to patrimonial damage, and, in cases provided by law, also for the moral damage".
VI.-1:101(2): "Where a person has not caused legally relevant damage intentionally or negligently that person is accountable for the causation of legally relevant damage only if Chapter 3 so provides".
VI.-1.101(1): "A person who suffers legally relevant damage has a right to reparation from a person who caused the damage intentionally or negligently or is otherwise accountable for the causation of the damage."

\section{VI.-1:103: "Scope of application} VI. - 1:101 (Basic rule) and VI. - 1:102 (Prevention):

(a) apply only in accordance with the following provisions of this Book".

VI.-2:101(1): "Meaning of legally relevant damage

(1) Loss, whether economic or non-economic, or injury is legally relevant damage if: [...]

(b) the loss or injury results from a violation of a right otherwise conferred by the law; or

(c) the loss or injury results from a violation of an interest worthy of legal protection".

Art. 1998: [Liability without illegality or fault]

(4) "The damage shall not be compensated for, were it was caused upon the request or with the consent of the damaged person, with the condition that the person knew or ought to have to know the consequences of the request or of the consent and, if author's deed does not contradict the norms of ethics and morality".
VI.-5:101: "Consent and acting at own risk

(1) A person has a defence if the person suffering the damage validly consents to the legally relevant damage and is aware or could reasonably be expected to be aware of the consequences of that consent.

(2) The same applies if the person suffering the damage, knowing the risk of damage of the type caused, voluntarily takes that risk and is to be regarded as accepting it". 


\begin{tabular}{|l|l|}
\hline No equivalent & $\begin{array}{l}\text { VI.-6:102: "De minimis rule } \\
\text { Trivial damage is to be disregarded". }\end{array}$ \\
\hline $\begin{array}{l}\text { Art. 2021: "Loss upon Fraudulent } \\
\text { Misrepresentation }\end{array}$ & $\begin{array}{l}\text { VI.-2:210: "Loss upon fraudulent mis- } \\
\text { representation }\end{array}$ \\
$\begin{array}{l}\text { another's fraudulent misrepresentation, } \\
\text { whether by words or conduct, shall be } \\
\text { compensated. } \\
\begin{array}{l}\text { (2) A misrepresentation is fraudulent if } \\
\text { it is made with knowledge or belief that } \\
\text { the representation is false and it is inten- } \\
\text { ded to induce the recipient to make a } \\
\text { mistake". }\end{array}\end{array}$ & $\begin{array}{l}\text { person as a result of another's fraudulent } \\
\text { misrepresentation, whether by words or } \\
\text { conduct, is legally relevant damage. } \\
\text { (2) A misrepresentation is fraudulent if } \\
\text { it is made with knowledge or belief that } \\
\text { the representation is false and it is inten- } \\
\text { ded to induce the recipient to make a } \\
\text { mistake". }\end{array}$ \\
\hline $\begin{array}{l}\text { Special statutory provisions outside the } \\
\text { Code }\end{array}$ & $\begin{array}{l}\text { VI.-2:203(1): "Loss caused to a natural } \\
\text { person as a result of infringement of his } \\
\text { or her right to respect for his or her di- } \\
\text { gnity, such as the rights to liberty and } \\
\text { privacy, and the injury as such are legal- } \\
\text { ly relevant damage." }\end{array}$ \\
$\begin{array}{l}\text { VI.-2:203(2): "Loss caused to a person } \\
\text { as a result of injury to that person's re- } \\
\text { putation and the injury as such are also } \\
\text { legally relevant damage if national law } \\
\text { so provides". }\end{array}$ \\
\hline
\end{tabular}




\section{Art. 19(1)-(5): "Reparation of Loss}

(1) Under law a person whose right or interest recognized by law was violated may claim the reparation of the full patrimonial and non-patrimonial loss caused thereby.

(2) Patrimonial loss includes expenses which the aggrieved party has incurred or will incur in the reinstatement of its right or interest recognized by law, destruction or damage to its property (real loss), as well as profits lost out of the violation of the right or interest recognized by law (lost profit).

(3) Non-patrimonial loss (moral loss) includes physical and psychologic, as well as reduction of the quality of life. In case of personal injury, it also includes the loss or reduction of a capacity of the human body (biological loss).

(5) Reparation of the loss involves the reinstatement of the aggrieved person in the situation that it would have been if the loss had not occurred".
VI.-2:101(3): "In considering whether it would be fair and reasonable for there to be a right to reparation or prevention regard is to be had to the ground of accountability, to the nature and proximity of the damage or impending damage, to the reasonable expectations of the person who suffers or would suffer the damage, and to considerations of public policy".

(4): "In this Book:

(a) economic loss includes loss of income or profit, burdens incurred and a reduction in the value of property;

(b) non-economic loss includes pain and suffering and impairment of the quality of life".

VI.-6:101(1)-(3):

(1) "Reparation is to reinstate the person suffering the legally relevant damage in the position that person would have been in had the legally relevant damage not occurred.

(2) Reparation may be in money (compensation) or otherwise, as is most appropriate, having regard to the kind and extent of damage suffered and all the other circumstances of the case.

(3) Where a tangible object is damaged, compensation equal to its depreciation of value is to be awarded instead of the cost of its repair if the cost of repair unreasonably exceeds the depreciation of value. This rule applies to animals only if appropriate, having regard to the purpose for which the animal was kept". 


\section{Art. 20(1) and (2): "Fault}

(1) Unless the law provides otherwise, a person is responsible solely for loss caused by its deed caused with fault, either in the form of intention or imprudence (culpa).

(2) A deed is made by intention if the person which made it knew the prejudicial character of the action or inaction, has foreseen its prejudicial consequences, wanted or admitted, consciously, the occurrence of those consequences".

Art. 20(3)-(5): "Fault

(3) The deed is made by imprudence (culpa) if the person who made it was aware of the prejudicial character of the action or the inaction, has foreseen its prejudicial consequences, but has recklessly considered that they shall be avoided or was not aware of the prejudicial character of its action or inaction, has not foreseen the possibility of occurrence of its consequences, although it ought and could have foreseen them. (4) There is gross negligence if a person is guilty of a profound failure to take such care as is self-evidently required in the circumstances.

(5) Where the law requires, for the occurrence of legal consequences of a deed, that it be made out of imprudence (culpa), the requirement is also considered satisfied if it had been made with intention".

\section{VI.-3:101: „Intention}

A person causes legally relevant damage intentionally when that person causes such damage either:

(a) meaning to cause damage of the type caused; or

(b) by conduct which that person means to do, knowing that such damage, or damage of that type, will or will almost certainly be caused".

\section{VI.-3:102: „Negligence}

A person causes legally relevant damage negligently when that person causes the damage by conduct which either:

(a) does not meet the particular standard of care provided by a statutory provision whose purpose is the protection of the person suffering the damage from that damage; or

(b) does not otherwise amount to such care as could be expected from a reasonably careful person in the circumstances of the case". 


\begin{tabular}{|c|c|}
\hline $\begin{array}{l}\text { Art. 19(4): [Loss of chance] „,Loss of } \\
\text { chance shall be repaired only if it con- } \\
\text { sists in the actual and certain disap- } \\
\text { pearance of a favourable eventuality. } \\
\text { The amount of such loss corresponds to } \\
\text { the lost chance and cannot be equal to } \\
\text { the advantage which would have been } \\
\text { derived if the chance had materialized“. }\end{array}$ & $\begin{array}{l}\text { VI.-2:101(2) and (3): } \\
\text { (2) "In any case covered only by sub-pa- } \\
\text { ragraphs (b) or (c) of paragraph (1) loss } \\
\text { or injury constitutes legally relevant da- } \\
\text { mage only if it would be fair and reason- } \\
\text { able for there to be a right to reparation } \\
\text { or prevention, as the case may be, under } \\
\text { VI. - } 1: 101 \text { (Basic rule) or VI. - } 1: 102 \\
\text { (Prevention). } \\
\text { (3) In considering whether it would be } \\
\text { fair and reasonable for there to be a right } \\
\text { to reparation or prevention regard is to } \\
\text { be had to the ground of accountability, } \\
\text { to the nature and proximity of the dama- } \\
\text { ge or impending damage, to the reason- } \\
\text { able expectations of the person who suf- } \\
\text { fers or would suffer the damage, and to } \\
\text { considerations of public policy". }\end{array}$ \\
\hline
\end{tabular}




\section{Art. 2010: "Liability for Damage Cau- sed by Person under a Legal Protec- tion Measure}

(1) Where a person under a legal protection measure caused damage, liability shall lie on the provisional guardian, the trustee or where applicable the guardian or the institution where the person is interned, provided that they were obliged to supervise that person, unless they prove that the supervision obligation was duly fulfilled.

(2) The obligation to compensate for the damage caused by a person under a legal protection measure binding on the persons mentioned in paragraph (1) does not cease where that person reacquired legal capability.

(3) Where the provisional guardian, the trustee or where applicable the guardian brought to account in conformity with para.(1) has died or does not dispose of means sufficient to compensate for the damage, while the author of the damage has such means at his avail, the court, having regard of the material state of the injured person and of the author of damage, the author's degree of responsibility, as well as other circumstances, is entitled to decide on total or partial compensation for such damage on account of the author".

Art. 2008: [Liability of an educational or medical institution]

(2) "Where the minor under 14 caused the damage while being under the supervision of an educational or medical institution or of a person bound to supervise the minor under contract, these entities shall be liable for the damage caused, unless they prove that the supervision obligation was duly fulfilled".
VI.-3:104(2): “Accountability for damage caused by children or supervised persons

[...]

(2) An institution or other body obliged to supervise a person is accountable for the causation of legally relevant damage suffered by a third party when:

(a) the damage is personal injury, loss within VI. - 2:202 (Loss suffered by third persons as a result of another's personal injury or death) or property damage;

(b) the person whom the institution or other body is obliged to supervise caused that damage intentionally or negligently or, in the case of a person under eighteen, by conduct that would constitute intention or negligence if it were the conduct of an adult; and

(c) the person whom the institution or other body is obliged to supervise is a person likely to cause damage of that type". 


\section{Art. 2005: "Principal's Liability for} Act of Agent

(1) The principal is liable for the damage caused by imputable act, and when provided by law, without culpability, by the manager, employee or any other person subordinated to the principal (agent) during exercise of the functions that have been entrusted.

(2) In case if the principal caused the damage intentionally, the injured person may choose to seek compensation for the damage only from the principal, only from the agent, or from both jointly and severally".

Art. 2008: [Liability of and for minors]

(1) "Damage caused by a minor under the age of 14 shall be compensated for by the parents (adoptive parents) or by the guardian, unless they prove absence of fault in supervising or educating the minor".

Art. 2009:

(2) "Where the minor between 14 and 18 years of age does not have property or income sufficient to compensate for the damage inflicted, this should be compensated for, in whole or in the uncompensated part, by the parents (adoptive parents) or the trustee, unless they prove that the supervision obligation was duly fulfilled. The provisions of the Art. 2008 paragraph (4) shall apply accordingly".
VI.-3:201(1): “Accountability for damage caused by employees and representatives

(1) A person who employs or similarly engages another is accountable for the causation of legally relevant damage suffered by a third person when the person employed or engaged:

(a) caused the damage in the course of the employment or engagement; and (b) caused the damage intentionally or negligently, or is otherwise accountable for the causation of the damage".

VI.-3:104(3):

"However, a person is not accountable under this Article for the causation of damage if that person shows that there was no defective supervision of the person causing the damage". 
Art. 2014: "Liability for Damage Caused by Animals

(1) The owner of an animal or the person that is using an animal during work is liable for the damage caused by it, either if he were under his surveillance or escaped from it. The obligation to compensate does not arise where the damage was caused by a domestic animal designated for professional activity, for business activity or for obtaining means for owner's maintenance and the owner has ensured due care for animal's surveillance, while the damage would have been caused even in case of such due care".

Art. 2015: "Liability for Damage Caused by Collapse of Building

(1) The owner is bound to compensate for the damage caused by general or partial collapse of a building, where the collapse is due to the lack of according maintenance or a defect in construction".

Art. 2016: "Liability in Case of Falling or Spill from Building

(1) Where the damage has been caused due to the fact that something fell or spilt from the building, the person having the building in possession shall be held liable. This rule shall not apply in the case when the damage was caused by an event provided by the provisions of article 2012 or due to the fault of the injured person.

(2) The owner is to be regarded as possessing the building, until proven otherwise".
VI.-3:203: “Accountability for damage caused by animals

A keeper of an animal is accountable for the causation by the animal of personal injury and consequential loss, loss within VI. - 2:202 (Loss suffered by third persons as a result of another's personal injury or death), and loss resulting from property damage".

VI.-3:202: “Accountability for damage caused by the unsafe state of an immovable

(1) A person who independently exercises control over an immovable is accountable for the causation of personal injury and consequential loss, loss within VI. - 2:202 (Loss suffered by third persons as a result of another's personal injury or death), and loss resulting from property damage (other than to the immovable itself) by a state of the immovable which does not ensure such safety as a person in or near the immovable is entitled to expect having regard to the circumstances including:

(a) the nature of the immovable;

(b) the access to the immovable; and (c) the cost of avoiding the immovable being in that state.

(2) A person exercises independent control over an immovable if that person exercises such control that it is reasonable to impose a duty on that person to prevent legally relevant damage within the scope of this Article.

(3) The owner of the immovable is to be regarded as independently exercising control, unless the owner shows that another independently exercises control". 
Art. 2013: "Liability for Damage Caused by Source of Increased Danger

(1) Persons whose activity is related to a source of increased danger for those around it (exploitation of vehicles, installations, mechanisms, use of electric energy, explosives, construction works etc.), are bound to compensate for the damage caused by the source of increased danger, unless they prove that the damage is due to an event provided by the provisions of article 2012 (save for cases when the damage occurred as a consequence of exploitation of air vehicles) or to the fault of the injured person. (2) The obligation to compensate for the damage pertains to the person that possesses the source of increased danger based on the right of ownership or on other legal grounds, or to the person that undertook surveillance of the source of increased danger.

(3) The possessor of the source of increased danger shall not be liable for the damage caused, if he proves that the source of increased danger got out of his possession as a consequence of illegal acts of third parties. In such case, the liability pertains to the person that illicitly acquired the source of increased danger. Inasmuch as the fact that the source of increased danger got out of the possession of the legal holder is imputable to him, he shall be liable for the damage jointly and severally with the person that obtained illegal possession of the property.

(4) The possessors of sources of increased danger are jointly and severally liable for the damage caused to a third party by interaction of those sources (collision of vehicles etc.).

(5) The damage caused to the possessors of sources of increased danger as a result of interaction of those sources shall be compensated for in accordance with Article 1398".
VI.-3:205: “Accountability for damage caused by motor vehicles

(1) A keeper of a motor vehicle is accountable for the causation of personal injury and consequential loss, loss within VI. - 2:202 (Loss suffered by third persons as a result of another's personal injury or death), and loss resulting from property damage (other than to the vehicle and its freight) in a traffic accident which results from the use of the vehicle.

(2) "Motor vehicle" means any vehicle intended for travel on land and propelled by mechanical power, but not running on rails, and any trailer, whether or not coupled".

\section{VI.-3:206: "Accountability for damage caused by dangerous substances or emissions}

(1) A keeper of a substance or an operator of an installation is accountable for the causation by that substance or by emissions from that installation of personal injury and consequential loss, loss within VI. - 2:202 (Loss suffered by third persons as a result of another's personal injury or death), loss resulting from property damage, and burdens within VI. - 2:209 (Burdens incurred by the State upon environmental impairment), if:

(a) having regard to their quantity and attributes, at the time of the emission, or, failing an emission, at the time of contact with the substance it is very likely that the substance or emission will cause such damage unless adequately controlled; and

(b) the damage results from the realisation of that danger.

(2) "Substance" includes chemicals (whether solid, liquid or gaseous). Microorganisms are to be treated like substances. 


\begin{tabular}{|c|c|}
\hline & $\begin{array}{l}\text { (3) "Emission" includes: } \\
\text { (a) the release or escape of substances; } \\
\text { (b) the conduction of electricity; } \\
\text { (c) heat, light and other radiation; } \\
\text { (d) noise and other vibrations; and } \\
\text { (e) other incorporeal impact on the en- } \\
\text { vironment. } \\
\text { (4) "Installation" includes a mobile in- } \\
\text { stallation and an installation under con- } \\
\text { struction or not in use. } \\
\text { (5) However, a person is not accountable } \\
\text { for the causation of damage under this } \\
\text { Article if that person: } \\
\text { (a) does not keep the substance or opera- } \\
\text { te the installation for purposes related to } \\
\text { that person's trade, business or professi- } \\
\text { on; or } \\
\text { (b) shows that there was no failure to } \\
\text { comply with statutory standards of con- } \\
\text { trol of the substance or management of } \\
\text { the installation". } \\
\text { VI.-3:207: "Other accountability for } \\
\text { the causation of legally relevant da- } \\
\text { mage } \\
\text { A person is also accountable for the cau- } \\
\text { sation of legally relevant damage if na- } \\
\text { tional law so provides where it: } \\
\text { (a) relates to a source of danger which is } \\
\text { not within VI. - } 3: 104 \text { (Accountability } \\
\text { for damage caused by children or super- } \\
\text { vised persons) to VI. - } 3: 205 \text { (Accounta- } \\
\text { bility for damage caused by motor vehi- } \\
\text { cles); } \\
\text { (b) relates to substances or emissions; or } \\
\text { (c) disapplies VI. - } 3: 204 \text { (Accountabili- } \\
\text { ty for damage caused by defective pro- } \\
\text { ducts) paragraph ( } 4 \text { )(e)". }\end{array}$ \\
\hline $\begin{array}{l}\text { Art. 1999(2) and (3): [Concurrence of } \\
\text { Actions] } \\
\text { (2) "The provisions of this chapter are } \\
\text { not applicable when their application is } \\
\text { contrary to other legal provisions. } \\
\text { (3) The provisions of this chapter shall } \\
\text { not preclude the application of other le- } \\
\text { gal means of defense on other legal } \\
\text { grounds". }\end{array}$ & $\begin{array}{l}\text { VI.-1:103(c) and (d): } \\
\text { "VI.-1:101 (Basic rule) and VI.-1:102 } \\
\text { (Prevention): } \\
\text { (c) do not apply in so far as their appli- } \\
\text { cation would contradict the purpose of } \\
\text { other private law rules; and } \\
\text { (d) do not affect remedies available on } \\
\text { other legal grounds". }\end{array}$ \\
\hline
\end{tabular}




\begin{tabular}{|l|l|}
\hline No equivalent & VI.-5:102(2) \\
& (2) “However, no regard is to be had to: \\
(a) an insubstantial fault of the person \\
suffering the damage; \\
(b) fault or accountability whose contri- \\
bution to the causation of the damage is \\
insubstantial; \\
(c) the injured person's want of care \\
contributing to that person's personal in- \\
jury caused by a motor vehicle in a traf- \\
fic accident, unless that want of care \\
constitutes profound failure to take such \\
care as is manifestly required in the cir- \\
cumstances".
\end{tabular}

